石酒技衔協会誌 第 60 巻 第 6 号 (平成 7 年11月)

JOURNAL OF THE JAPANESE ASSOCIATION FOR PETROLEUM TECHNOLOGY

VOL. 60, NO. 6 (Nov., 1995)

\author{
資料 \\ 開発・生産部門シンポジウム \\ 「水平坑井の仕上げ技術と油層評価」*
}

\title{
SYMPOSIUM
}

\section{Completion and reservoir engineering aspects of horizontal well}

パネルディスカッション**

Panel discussion

在原：これからの1時間は, 本日のシンポジウムのプ レゼンテーションおよびそれに対する質疑応答で足りな かったところをカバーするような形で，パネルディス カッションを進めて行きたいと思います。会場の皆さん の積極的な参加を期待します。

本日のシンポジウムでは水平坑井について有意義でか つ多面的なプレゼンテーションが行われたように思いま す。石油技術協会のシンポジウムとしては，4年前に作 井部門でこの水平坑井を取り上げ，また，咋年は石油公 団の国際シンポジウムで李取り上げられました。さら に, 現在活動中の生産技術委員会の坑井圧力解析分科会 でも，今年は水平坑井を取り上げたことがあったかと思 います。本曰の発表を聴いて，過去数年の間に各石油会 社においても水平坑井に対し，かなりの実績を上げられ ていることが解りました。

このパネルディスカッションでは始めにパネラーの 万々から本日の発表で言い足りなかったことを話してい ただきたいと思います。まず水平坑井の仕上げのデザイ ンを考える上でよ゙のようなポイントが重要であるのかを

$*$ 平成 7 年 6 月 9 日, 平成 7 年度石油技術協会春季講演会に招ける 開発・生産部門シンポジゥム「水平坑井の仕上代技術と油層 評亚」でのパネルディスカッション Panel discussion at the 1995 JAPT Development and Production Technology Symposium entitled "Completion and reservoir engineering aspects of horizontal well", held in Makuhari, Chiba, Japan, June 9, 1995

**司会：在原典男 (早稲田大学), パネラー：柳澤研二(㑣ジャ ペックスオマーン), 三谷丈志 (アラビア石油(侏), 影山 隆 (石油資源開発俶)，清水信寿（石油公団石油開発技術セン 夕一), 島本辰夫 (帝国石油(侏), 安楽敏行 (石油資源開発(㑣)

Copyright (C) 1995, JAPT
楖沢さん，三谷さん，それから影山さんに何いたいと思 います。その後に水平坑井の評価について話し合って行 きたいと思います。

柳沢：オマーンではすでに非常に多くの水平坑井が仕 上げられているという状況から，当社ジャペックスオ マーンでは試行として水平坑井を仕上げるのでなく, 初 めから適切に水平坑井を仕上げる必要がありました。そ こでまず周边の石油会社でどのような水平坑井の仕上げ 方法を採用しているのかを十分に調查しました。その中 で当社の油層と同様の油層を持つオキシデンタル社の データを参考にして最終的には裸坑仕上げを採用するこ とにしました。また酸姏理を行わなくと古生産性は非常 に良いというオキシデンタル社の実績から, 当社でも酸 処理は行わないことにしました。

三谷：アラビア石油の水平坑井を仕上げる主目的は ウォータ一カットの減少およびウォーターブレークス ルーを遅らせるということです。先ほどの発表のときに 時問の関係で言えなかったことをここで少し説明させて いただきます。1989年に当社が初めて仕上げた水平珫井 は砂岩層に対するすのでありました。このとき使用した 泥水の比重は10.8から 12.1 PPGであり,これは事前に 行った岩石力学試験などから，この程度の泥水を用いれ ば掘削中の坑井の崩阹を防ぐことができると予想したか らです。また, この秒岩層のキャップロックの泥岩が水 平坑井掘削の際に問題になるのではないかと考えて, 掘 削方法としてはショートラディアス法を選択しました。 水平坑井の水平区間距離は, ウォーターコーニングによ る水の生産を考慮して会社の設定したその坑井の目標産 出レートがウォーターコーニングの臨界産出レート以下 
であるように決定しました。以上が当社の最初の水平坑 井を仕上げる際に行った作桑です。その後はこの経験を 生加して，1993年より第 1 次水平坑井掘削キャンペーン ということで 7 本の水平坑井を仕上げました。この際, 掘削方法としてはミディアムラディアス法を採用し，仕 上げはライナーをセットし，セメンチングを行った後， TCP でパーフォレーションを行うことにしました。ミ ディアムラディアス法を採用したことにより，より長い 水平部を仕上げることが可能となり，またこのため，よ り一層の生産性の向上が期待でき，さらにライナー・セ メンチング・TCPによって仕上げを行うことによって アンダーバランスでパーフォレーションを行うことがで きるようになり，坑井のダメージを最小限に抑えること ができるようになりました。また，将来の改修作業も容 易に行えるなど，この仕上げ力法には多くの利点があり ます。さらに, 実際に第 1 次掘削キャンペーンを行って 解ったことは，この眇岩層では坑井刺激を行わなくて ま, 今回の仕上げ方法を用いれば非常によい生産性が得 られるということです。

また，私の発表のときにあった質問についても，ここ で答えさせていただきたいと思います。先ほど，水平坑 井においてはその両端部からの流体の坑井への流入が通 常多いと考えられることから，そこからウォーターコー ニングが起こるのではないかというご質問をいただきま した。文献などでは TCP のショットデンシティーを水 平坑井の水平部の場所によって変えて，これを防ぐなど と言うことあ書かれていますが，当社ではいまのとこ ろ，このようなことは行ってはいません。水平坑井の仕 上げ以後十分な生産実績がいまのところないので，これ らについては今後の課題と考えています。

さらに我々の経験加ら水平坑井全般について言えるこ とは, 掘削前に砂の発達が非常に良いと考えた場所に掘 削を行った場合であ坑井の水平部全体において砂が発達 しているということは希で，したがって通常水平部の中 でも砂の発達の度合によって生産に寄与する部分と寄与 しない部分があるということです。こうした岩相の側方 変化が, 流体が坑内へ流入する状況に与える影響につい てす，今後考慮する必要があると考えています。

影山：当社の場合はアンカー仕上げで ECP を使用し て仕上げを行いましたが, 掘削に先立って仕上げ方法に ついては十分に検討を行いました。アンカー仕上げを選 択した経緯は, 対象層がフラクチャ一貯留岩であり，こ のような油層にセメンチングを行った場合には坑井の生 産障害が起こるのではないかと考え，なるべくこの障害 が少なくなるようにアンカー仕上げを採用しました。そ れからまた坑井の崩壊が予想されたこともアンカーを入
れることにした理由の1つです。ECPについては今回 水平部に5つセットしたわけですが，これらは検層 (LWD) の結果から分けられた岩相の境界にセットしま した。またこの油層は今のところ水押しがあるかどうか は分からないのですが，下部に掘込んだ部分から水の産 出の可能性があるので, あし水の産出があった場合には 坑内の ECP 部にインフレータブルパッカーをセットし て遮水することを考えています。また，今回行った PLT の結果をみると ECPをセットすることにより PLT の解析が可能となり，ECP はPLT 解析にとって 非常に有効であることが解りました。

在原：どうもありがとうございました。ここで会場の みなさんのご意見すいただきたいと思います。会場の皆 さんで水平坑井仕上げについてコメント，質問などあり ませんでしょうか。

増田（東大）：実際に水平沆井を仕上げる祭にアン カー仕上げとケーシング・セメンチング・パーフォレー ション仕上げのどちらが一般的に用いられるのでしょう 加。

柳沢：水平坑井に対するセメンチングは非常に難しい と言われています。セメントが固まる際に比重差が坑内 にできてセメントが均等に固まらないからです。オマー ンではPDO社においてセメンチングを行う場合がある と聞いていますが，これはオマーンの南部地域で油層が 砂岩層であり，坑井の前壊が予想されるような特別の場 合にセメンチングを行っているようです。

三谷：アラビア石油であセメンチングがうまくいかな いのではということは十分考えて扔り，この予防的な措 置として ECPのセットも併せて行っています。

在原：会場の方でこれについて何かご意見はございま せ九加。

森田（早大）：私の経験では，炭酸塩岩層の場合， パーフォレーテッドライナーを入れるべきだと考えま す。その理由は, 通常は坑井の崩壇の危険性が無い油層 の場合でも，酸処理を行ったときに坑井の崩壊の危険性 が高くなるからです。砂岩層では，必ず岩石の強度を調 べて, あしその砂岩層が砂岩の固まりとして前壊する夕 イプであ礼ばライナー管がパーフレーテッドライナー 仕上げ定採用し，それ以外の場合ではプレパックトライ ナー仕上げを採用しています。プレパックトライナーを 採用する際, サービスカンパニーが推萀するグラベル は,グラベルパック時と同様に砂岩の粒径よりあ小さな グラベルでありますが，これはプラッギングの問題があ ります。私の経験ではグラベルパックのときには殿留層 砂岩の粒径より細かいグラベルを用い, プレパックト ライナーの上きには貯留層砂岩の粒佳よりあかなり大き 
なグラベルを用いることでプラッギングの問題などは解 消され，生産性向上の点でむ非常に良い結果が得られて います。また, やや水平坑井の仕上げの話題からはそれ ますが，一般的に最近は水平玾井が垂直坑井より良いと 強調され過ぎたため，これによる慗害も起こってきてい るように思います。その弊害とは，水平坑井は坑井が崩 壊しやすく，したがってプレパックトライナーなどを使 用する必要があるということです。このため逆に最近 は，1960年代に流行した垂直坑井を完全な裸坑仕上げに することが見直されてきています。これにより費用の削 減ができ，また坑井が掘削時も生産時も非常に安定する のです。実際にこのような仕上げをした坑井の数は増加 してきています。石灰岩層では水平坑井でよいのです が，砂岩層では坑井の不安定さが顕著です。1960年代に はこの仕上げ方法が盛んでありましたが，パーフォレー ション技術の進歩により，その後この方法は用いられな くなりましたが，現在は再び見直されてきています。

三谷：坑井の安定ということを考えるとそのと怙りか もしれませんが，アラビア石油の場合のように水の生産 を抑えるということを考えた場合，その上うな方法の利 点は䵵いように思います。

森田（早大）：坑井すべてを裸坑にする必要はないわ けですし，垂直坑井を仕上げてあ遮水作業は可能である と思います。

三谷：当社でもそのような作業は実際に行ってきまし たが，結果はあまり良くないというのが現実です。

森田（早大：確かにそうかるしれませんが，あまり に水平坑井を採用しすぎるということは問題ですし，さ まざまな掘削仕上げ方法すその利点を生かして，状況に 応じてそれらの方法を併用した方が良いと思います。

会場 1 : 炭酸塩岩の場合に酸処理を行うためパーフォ レーテッドライナーを用いると森田さんは言わ机ました が，本当に酸処理により油層は崩塤するのでしょうか。

森田（早大）：理論的には炭酸塩岩の酸処理を行えば すべての坑井は崩れなければならないのですが，実際に はそうではないのですが，なぜパーフォレーテッドライ ナーを入れるかというとパーフォレーテッドライナーを 入れても弊害はないし，1回の酸処理では，たとえ崩れ なくとも数回酸処理を行えば崩れる可能性があるからで す。

有馬 (アラビア石油)：先ほど, 当社の三谷より説明 がありましたが, アラビア石油では業者にコアを提供し て岩石力学試験を行わせ, 泥水の比重や仕上げのデザイ ンなどを考えたのですが，三谷の説明にあった砂岩層に 水平坑井を掘削した際, 岩石力学試験の結果が悲観的で ありそうとう比重を上げてる水平坑井は掘削できない
という結果がでました。ところが実際に掘削を行ってみ ると掘削は十分に行えましたし，さらに掘削中に掘管が 抑留された際, 泥水比重を落とし難を逃れたのですが, その後はそれ以前より軽い泥水を用いても掘削が可能で ありました。そうしたことから考えて岩石力学試験から 得たような重い泥水は, 経験的に使用する必要が無いこ とがわかりました。対象となった仯岩層はどちらかとい えば未固結な仯岩層であるにもかかわらず掘削が可能で あったのです。このことにより，それ以後当社が掘削し た水平坑井では，当社が垂直坑井を掘削する際に用いる 通常の比重の泥水を使用しました。このことから考える と岩石力学試験梳信用できないのではとも考えているの ですが，いかがなるのでしょうか。

森田（早大）：正しいモデルを使用してスタディを行 えばそのようなことは起こりません。業者の使用してい るモデルが間違いなのです。モデルはそのフィールドで キャリーブレーションしたあのでなくてはならず，そう いう意味で業者のモデルは使用できないのです。業者の モデルあ実際の掘削データなどでキャリブレーションす れば使用できるはずです。

椙岡（帝国石油）：水平坑井の不安定性について当社 の島本が説明いたしましたように，当社が水平坑井を仕 上げた対象層は垂直坑井においても出砂が確認されてお り, 水平玾井を仕上げた場合には出砂対策が重要課題で あると考えていたので，デュアルラップスクリーンを仕 上げに用いました。その後の生産の減退挙動を見ている と我々の計算が正しければ,これは対象層の崩壊による 生産障害によるものではなく, 油層の圧力減退によるも のと考えられます。よって，出砂という観点から見れば 通常考えられているよりは水平坑井は安定しているので はないかと思います。森田さんがモデルて計算された場 合, 垂直坑井之水平坑井の安定性はどの程度違うので しょうか。

森田（早大：理論的には水平坑井之垂直坑井の安定 数は数百 psi 程度しか違いません。ただし，よく一般に 水平坑井を掘削すると出仯が止まるように勘違いされる のは, 水平坑井の場合は坑内の容積が大きいため, 坑口 に現れる出砂の時期が垂直坑井に比べて遅くなることに 上ります。水平坑井の場合, 水平部がある程度砂で満た されてから出砂現象が坑口で観測されるのですが，私の 経験加ら出砂量之言うことについては水平玾井の方が 垂直坑井より多いと考えます。

在原：どうあありがとうございました。それではここ でやや話題を变えてみたいと思います。島本さんは坑井 テスト解析を油層解析に生加すというスタディをやら れ，また安楽さんはかなり水平坑井のテスト解析につい 
てはいろいろとご意見があると思います。坑井テスト解 析および油層解析という面でご意見があればお聞かせ願 いたいのですが。

島本：先ほどのプレゼンテーションのときにはあまり 触れなかったことがあります。対象となった頸城の油層 自体は非常に不均質性が高いのですが，私が行ったテス 卜解析においては均質なモデルを使用しました。そのた めテストのマッチングにおいては非常に良いすのが得ら れたのですが，それは単に結果が合っただけなので，解 の信頼性については定かではありません。また水平部の 長さについては，周边の坑井のテストから得られた浸透 率と層厚などを考えて計算し求めたものなのですが，こ れは掘削特のショーイングなどと考えて香はぼ良いよう に考えます。ただし，水平部でのフローの状況について は, 油層の不均質性など季考えると出るところからは出 るし, 出ないところからは出ないと思われます。PLT を行えばこれらはわかるはずなのですが，頸城の場合は 産出流量が少ないので，拈そらくPLTを行っても良い データは得られないのではと考えて，PLTは行いませ んでした。現時点ではこれらが課題となっています。ま た, 油層に不均質性がある場合には, 水平坑井のテスト 解析はかなり難しいと思います。これらを水平坑井の解 析についての一般的な課題であると思います。

在原：清水さんに坑井亡油層との干路についてお同い したいのですが。

清水：石油公団 TRCでは水平坑井と油層との相互関 係ということについて平成元年度より研究してきていま す。この研究では水平坑井のモデルを構築し，このモデ ルから得られる計算值を実験室で得られるデー夕と比較 してきましたが，この場合モデルから得られる值は実験 室で得られた值と非常によく合うことは検証することが できました。ただし，実験室では温度は常温であり，圧 力は夹際の坑井に比べれば桁違いに低いわけですから， 実験室レベルで検証されたモデルが，果たして実際の フィールドであ使用できるのかどうかということをずっ と考えてきました。坑内の圧力損失についてはご存じの 亡おり摩擦, 重力, 加速の 3 種類があるのですが, 水平 坑井の水平部でこの3つのうちむっと屯支配的なむのは 何なのか與味があり，今回由利原のデータを見てみまし た。先ほどの発表の中でも結論としましたが, 流量の少 ない所では重力項が 1 番大きいということは解りまし た。しかし，流量の多い所で，しかも水平部がほぼ実際 に水平に近い場合には摩擦の項がどの程度効いてくるの かなどは, 現在もいろいろと考えています。また, 由利 原の場合は油層に不均質性があったわけですが，均質な 油層に水平坑井を仕上げた場合には水平坑井の挙動はど
うなるのか非常に興味があります。石油公団ではフィー ルドを持っていないので，石油会社の協力を得なければ 解決できない問題がこのように多数ありますし，向し今 後データを提供していただければ嬉しいのですが。この ような意味からも今回の由利原は非常に與味深いス夕 ディができました。

在原：安楽さんいかがでしょうか。

安楽：理論的なことで 1 つ皆さんと確認したいことが あります。基本に戻って水平坑井がなぜ垂直坑井よりあ 生産性が高いのかということを考えたいと思います。こ のことに対する説明は，水平坑井は垂直坑井に比べて油 層との接触面積が大きいので流体が坑井八流れ込みやす いという説明が一般的になされていると思いますし，こ の考え方は一見納得できます。このことを生力解析の面 から考えると，水平坑井をフローさせた場合，アーリー ラディアル，アーリーリニアそしてスードラディアルと フロー状態が变化していくわけですが，このスードラ ディアルとなった時に水平坑井と垂直坑井の生産性を比 較した場合，水平坑井の方が見かけ上のウェルボアが大 きくなるから生産性が良いのだ之私は考えているわけで すが，この点に関してみなさんはよ゙のように考えられて いるのでしょうか。

在原：ひととおり坑井テス卜解析, 油層評価などにつ いてパネラーの方々から意見を伺いましたが，会場の 万々から質問ご意見などをいただきたいと思います。

井上（帝国石油）：安楽さんのご質問の件について話 したいと思います。私は水平玾井の生産性を考える場 合, どの時点での生産性が水平坑井のメリットとして受 け入れられるかと言うことがポイントだと思います。私 ど委帝国石油で行ったフラクチャリングを例に取って考 えると, 当社がこのフラクチャリング作業の前に行った ケーススタディの際, ガス層の浸透率とフラクチャー内 のコンダクティビティーを対比することによって，生産 性の高い期間，つまりリニアーフローの期間をどれだけ 長く保つことができるのかが決まることが解りました。 当然のことですが油層の浸透率が低くてフラクチャーの コンダクティビティーが高い場合，つまりコントラスト の大きい場合にリニアフローの期間を長く保つことがで きるので，このことが坑井の経済性を考える場合にも非 常に大きな因子となるのです。同じことは水平坑井につ いても言えることで，抢そらく低浸透率の油がス層に対 し長い水平珫井を掘削し，しか6坑内の压力損失がほと んど無い場合に水平坑井のメリットが生かされ，また， これと逆の瑒合には水平坑井のメリットは生かされない と考えられます。

有馬 (アラビア石油)：安楽さんの話で, 生産性の向 
上ということに関しては，水平坑井の場合は接触面積が 大きくなるから生産性が向上するということを言われて いましたが，私もそれで良いと思います。ただし，私は 水平坑井を掘削すれば油ガス層開発に際し必要な坑井数 が隇るということが水平坑井のもっとあ大きなメリット と考えています。水平坑井と垂直坑井を比較した場合, 排油範囲, 坑井間隔ということが問題になると思うので す。いま当社で問題としているのは, ウォーターブレー クスルーを荤らせるためどういう配置で, どういった長 さの水平坑井を仕上げれば良いのかということで，これ については議論をしていますが，一本の水平坑井の生産 性うんぬんということはあまり議論の対象にはなってい ません。つまり，少なくとあ当社では，水平坑井は ウォーターブレークスルーを遅らせて掃攻率を上げる一 番経済的な手法として捕えていますので，ただ単に水平 坑井の生産性を考えて，あれが良い悪いということは， あまり意味がないのではと考えます。

在原：アラビア石油の場合には水平坑井をりエント リーで仕上げることああり，この場合は費用も新堀で垂 直坑井を掘るよりも安く抑えられるということなので, 水平坑井の経済性は非常に良いというお話む本日の発表 の中であったように記憶します。さて，そのほかに何か ございませんか。

会場 2 : 先ほどから水平坑井の生産性という話が出て いますが，これは極論すれば縦方向の浸透率ではないか 之私は考えます。例えばシェルなどは三次元震探をかけ ないところには水平坑井は掘らないと言っております。 実際にシェルでは最む孔隙率, 浸透率の良さそうなとこ ろに坑井を配置しているようです。さらにシュルンベル ジェなどはLWDなどを用いてロギングから浸透率を定 量的に評価することむできると言っていますし，やはり $K_{V} / K_{H}$ をどう上げるか， $K_{V}$ の良いところをどう狙うか とその刃ではないかと思って扔ります。安楽さんのご質 問の答えにはならないかもしれませんが，私はポイント はそこではないかと思っています。

森田（早大：私はほと儿どの水平坑井というのは本 当に水平ではないので, 思ったより $K_{V} / K_{H}$ が問題にな らないことが多いと思います。 $K_{V} / K_{H}$ が小さい場合に は意図的に坑井を垂直方向にく㱛らせますので， $K_{V} / K_{H}$ はそれほど問題にはならないのです。㫗ちろんガス/ ウォーターコーニングを防ぐ場合には坑井を水平に掘削 するわけですが，ただ単住生産性の向上を狙って水平坑 井を掘削する場合には，意図的に坑井をく好らせて $K_{V} /$ $K_{H}$ の効果をキャンセルするように坑井は仕上げられま す。よって $K_{V} / K_{H}$ はあまり問題ではないように思いま す。それから北海の方では地層が不均質なので, 水平坑
井を掘削する場合には油ガス層の生産性の良い部分を求 めてハンティングをするように水平坑井を掘削していま す。それから水平陸井とフラクチャリングについてなの ですが，フラクチャリングの場合は地層の圧力が下がれ ば下がるほに゙きれいなフラクチャーができますが，水平 坑井の場合は逆に地層の圧力が下がれば下がるほゼいる いろなトラブルが起きるので, これらの特性を考慮して 両者をうまく利用すれば良いと考えます。これらはあま りまだ良く一般に考えられていないことで, 例えば油田 開発の後期になっても単に水平玾井を掘削してしまうこ となどあ実際にありますので，むっとうまくやられた方 が良いと思います。

在原：さてはかにはいかがでしょうか。

清水：森田さんが言われるように意図的に坑井をくね らせた場合，坑井のクリーニングなどに問題は起こらな いのでしょうか。由利原の場合はバライトが坑内に残る など問題があったと思うのですが。

森田：バックリーミングすればバライトなどはかなり 減らせるのではないでしょうか。

影山：由利原の場合, 坑井仕上げに際して混水で仕上 げるか，またはブラインで仕上げるかということを考え たのですが, 結論としては泥水で什上げることにしまし た。というのは，対象層はブラインに対してセンシティ ブであると考元たからです。つまりブラインを使用した 場合に坑井の生産障害が起こるのではと考えたからなの です。また，バライトなどの固形物が坑内に残る可能性 があると考えて，仕上げ時にプロダクションチュービン グを入れた後、コイルドチュービングを用いて坑内を $\mathrm{KCl}$ ブラインに置き換えてなるべく坑内に泥水を残さ ないようにし，またクリーニングフローをできる限り大 きいフローレートで行いました。この時のレートは確か $400 \mathrm{k} l /$ day だったと思います。ただし，このレートで フローさせてあバライトは持ち上がらず，もっと大きな レートでフローができるならバライトの回収ができたの ではと思いました。したがって，今回はバライトが坑内 に残ってしまったのです。このクリーニングフローおよ び仕上げ用流体は各社どのように行っているのでしょう 加。

柳沢：オマーンではミ゙ディアムラディアスで水平坑井 を仕上げた場合，掘削終了と同時に循環を行い，坑内を 泥水から $\mathrm{NaCl}$ ブラインに置き換えています。クリーニ ングについてなのですが，最近行った水平坑井に対する 酸処理の際, 酸処理後のクリーニングは十分に行われて いないのではないかと思われる節がありました。水平坑 井ではかなりフローレートを上げてクリーニングを行っ ていますが，それでも十分とは言えないようなので，こ 
の点については十分に注意しなければならないと思いま क。

三谷：アラビア石油の場合, カーブ部分から TD まで オイルベースマッドで掘削を行い，その後，アンダーバ ランスの状態で TCPを行い，いったん $\mathrm{KCl}$ ブラインで 坑内を置換した後に TCPを回収しています。
在原：そろそろ時間となったようです。本日は多くの 方々から貴重な扰話を同え，私自身向いろいろと勉強に なりました。パネラーの方々あ本日はありがとうござい ました。これにてパネルディスカッションを終わりたい と思います。 